\section{Densely Planted Okra for Destructive Harvest: III. Effects of Nitrogen Nutrition}

\author{
Brian A. Kahn', Yaying $\mathrm{Wu}^{2}$, and Niels O. Maness ${ }^{3}$ \\ Department of Horticulture and Landscape Architecture, Oklahoma State \\ University, Stillwater, OK 74078-6027
}

\author{
John B. Solie ${ }^{3}$ and Richard W. Whitney ${ }^{4}$ \\ Department of Biosystems and Agricultural Engineering, Oklahoma State \\ University, Stillwater, OK 74078
}

Additional index words. Abelmoschus esculentus, fertilization, mechanical harvest, plant population, spacing

\begin{abstract}
Research was conducted to develop a cultural system that would permit a destructive mechanical okra [Abelmoschus esculentus (L.) Moench] harvest. Okra grown at a highly dense (HD) plant population of $25 \times 23 \mathrm{~cm}$ and destructively harvested by machine was compared with control plants spaced at $90 \times 23 \mathrm{~cm}$ and repeatedly and non-destructively harvested by hand. The control $\mathrm{N}$ fertilization regime was $45 \mathrm{~kg} \cdot \mathrm{ha}^{-1}$ of $\mathrm{N}$ preplant, followed by one or two topdressings, each with $22 \mathrm{~kg} \cdot \mathrm{ha}^{-1}$ of $\mathrm{N}$. Treatments applied to HD plots were designed to be multiples of the control $\mathrm{N}$ fertilization levels. Preplant fertilizer was added such that the sum of residual soil $\mathrm{N}$ plus the added fertilizer would total to 45,90 , or $135 \mathrm{~kg} \cdot \mathrm{ha}^{-1}$ of $\mathrm{N}$ for the standard, intermediate, and highest rates, respectively. Topdressing rates were 22,44 , or $66 \mathrm{~kg} \cdot \mathrm{ha}^{-1}$ of $\mathrm{N}$ for standard, intermediate, and highest, respectively. Topdressing was timed to follow a mechanical harvest of the HD plots. Since there was only one mechanical harvest in the two 1995 studies, topdress $N$ treatments did not affect yields from mechanical harvest in that year. Nitrogen treatments had few effects on fruit yield per hectare of HD okra, even when stem $N$ concentrations equaled or exceeded those of control plants. The highest $\mathrm{N}$ rate tended to delay fruit production. Increasing $\mathbf{N}$ rates did not affect the marketable fruit yield obtained by mechanical harvest of HD plants expressed as a percentage of the total cumulative marketable fruit yield from control plants. Physiological factors appear to be limiting the potential for densely planted okra in a destructive mechanical harvest system rather than horticultural factors such as $\mathbf{N}$ nutrition.
\end{abstract}

Recommended rates of $\mathrm{N}$ fertilization for okra vary greatly. Windham (1966) recommended from 27 to $54 \mathrm{~kg} \cdot \mathrm{ha}^{-1}$ of $\mathrm{N}$ for 'Clemson Spineless' okra, depending on soil type. Other $\mathrm{N}$ recommendations for maximum okra fruit yield included $112 \mathrm{~kg} \cdot \mathrm{ha}^{-1}$ (Ahmad and Tulloch-Reid, 1968), $135 \mathrm{~kg} \cdot \mathrm{ha}^{-1}$ (Asif and Greig, 1972), and $67 \mathrm{~kg} \cdot \mathrm{ha}^{-1}$ (Shrestha, 1983). Majanbu et al. (1985) recommended either 35 or $70 \mathrm{~kg} \cdot \mathrm{ha}^{-1}$ of $\mathrm{N}$ for okra, depending on cultivar. Majanbu et al. (1986) noted that the optimum rate of $\mathrm{N}$ for okra plant dry matter production $\left(100 \mathrm{~kg} \cdot \mathrm{ha}^{-1}\right)$ was higher than that for maximum edible fruit yield $\left(50 \mathrm{~kg} \cdot \mathrm{ha}^{-1}\right)$.

Received for publication 21 Nov. 2002. Accepted for publication 11 Apr. 2003. Approved for publication by the Director, Oklahoma Agricultural Experiment Station. This research was supported in part under project $\mathrm{H}-2026$. The information given in this publication is for educational purposes only. Mention of a trademark, proprietary product, or vendor does not constitute a guarantee or warranty of the product, nor does it imply approval or disapproval to the exclusion of other products or vendors that may also be suitable.

${ }^{1}$ Professor; to whom reprint requests should be addressed.E-mail: bakahn@okstate.edu

${ }^{2}$ Former Graduate Research Assistant.

${ }^{3}$ Professor.

${ }^{4}$ Professor Emeritus. controlled with preplant-incorporated trifluralin [2,6-dinitro- $N, N$-dipropyl-4-(trifluoromethyl) benzenamine] at $560 \mathrm{~g} \cdot \mathrm{ha}^{-1}$ (Bixby) or $840 \mathrm{~g} \cdot \mathrm{ha}^{-1}$ (Stillwater) and by hoeing. Insects were controlled with malathion $[O, O$-dimethyl $S$-(1,2-dicarboxyethyl) phosphorodithioate] at $1.4 \mathrm{~kg} \cdot \mathrm{ha}^{-1}$ as needed. No foliar disease control products were applied. Overhead sprinkler irrigation was provided to supplement rainfall based on subjective observations of plants and soils.

Seeds of 'Clemson Spineless 80' okra were sown in beds that were $2.1 \mathrm{~m}$ wide and not raised, using a vacuum-metering, ultranarrow-row precision planter developed by two of the authors (Solie and Whitney). Planting geometries were $25 \mathrm{~cm}$ between rows and 23 $\mathrm{cm}$ between plants within rows, with six rows per bed, in HD plots and $90 \mathrm{~cm}$ between rows and $23 \mathrm{~cm}$ between plants within rows, with two rows per bed, in the controls. Plots were $10 \mathrm{~m}$ long and were separated from each other by at least $3 \mathrm{~m}$ (Stillwater) or $4 \mathrm{~m}$ (Bixby) in all directions to minimize the chance of soluble soil $\mathrm{N}$ movement between plots. Plots were arranged in randomized complete blocks with three (Bixby, 1995) or four (Bixby, 1996; Stillwater, 1995) replications.

Soil samples were taken before planting in the spring of each year at a depth of 0 to $15 \mathrm{~cm}$. The control $\mathrm{N}$ fertilization level was $67 \mathrm{~kg} \cdot \mathrm{ha}^{-1}$ in 1995 , achieved by combining residual soil $\mathrm{N}$ and applied fertilizer to total $45 \mathrm{~kg} \cdot \mathrm{ha}^{-1}$ of $\mathrm{N}$ preplant and by one topdressing with 22 $\mathrm{kg} \cdot \mathrm{ha}^{-1}$ of $\mathrm{N}$. The control $\mathrm{N}$ fertilization level was $89 \mathrm{~kg} \cdot \mathrm{ha}^{-1}$ in 1996 , achieved by combining residual soil $\mathrm{N}$ and applied fertilizer to total 45 $\mathrm{kg} \cdot \mathrm{ha}^{-1}$ of $\mathrm{N}$ preplant and by two topdressings, each with $22 \mathrm{~kg} \cdot \mathrm{ha}^{-1}$ of $\mathrm{N}$. Treatments applied to HD plots were designed to be multiples of the control $\mathrm{N}$ fertilization levels. Preplant fertilizer was added such that the sum of residual soil $\mathrm{N}$ plus the added fertilizer would total to 45,90 , or $135 \mathrm{~kg} \cdot \mathrm{ha}^{-1}$ of $\mathrm{N}$ for the standard, intermediate, and highest rates, respectively. Topdressing rates were 22,44 , or $66 \mathrm{~kg} \cdot \mathrm{ha}^{-1}$ of $\mathrm{N}$ for standard, intermediate, and highest, respectively. Topdressing was timed to follow a mechanical harvest of the HD plots, and all plots (control and HD) were topdressed at the same time. The $\mathrm{N}$ fertilizer used was urea in all cases except for the preplant application at Bixby in 1995, when a complete fertilizer $(13 \% \mathrm{~N}-5.7 \% \mathrm{P}-10.8 \% \mathrm{~K})$ was used.

Plants in HD plots were destructively harvested once overmature fruit became evident, using an experimental machine developed by Oklahoma State Univ. Plants in the 1996 study regrew enough to allow a second destructive harvest. A sickle bar on the machine cut the plants at an average of $\approx 15$ to $20 \mathrm{~cm}$ above ground level over the full $10 \mathrm{~m}$ per plot. A gathering reel deposited the cut plants onto a conveyer belt that transported them to a collection bin. The entire apparatus was mounted on a frame adapted from a self-propelled sprayer. Bins were unloaded at the end of each plot. Stalks were defruited by hand and fruits (pods) were collected in bags for later grading and data recording. Fruits were graded into immature (pods $<5 \mathrm{~cm}$ long), marketable, and 
overmature (pods $\geq 5 \mathrm{~cm}$ long with palpable fiber development) categories, then weighed. Plants in control plots were repeatedly and non-destructively hand harvested up to three times per week. Data areas in control rows were $2.5 \mathrm{~m}$ long.

Four plants per plot were sampled shortly before mechanical harvest to determine height (distance from the soil to the highest plant part), $\mathrm{N}$ concentration in stems, and defruited dry weight at Stillwater in 1995 and at Bixby in 1996. Control plant samples were taken outside the areas chosen to undergo repeated hand harvests. After heights were measured, plants were cut at soil level. Stem samples for N concentration were taken by removing the top $15 \mathrm{~cm}$ (1995) or $10 \mathrm{~cm}$ (1996) of each plant, then using the next $30 \mathrm{~cm}$ (1995) or $20 \mathrm{~cm}$ (1996) of central axis stem tissue after removing any fruit or leaves from that section. Stem sections were washed in distilled water and dried (along with the rest of the defruited plant material) for $\geq 7 \mathrm{~d}$ at $50{ }^{\circ} \mathrm{C}$ before weighing. Stem sections then were ground with a Wiley mill to pass a 2-mm screen and analyzed for $\mathrm{N}$ by dry combustion.

Bixby, 1995. A preplant soil test indicated 19N-154P-271K $\left(\mathrm{kg} \cdot \mathrm{ha}^{-1}\right)$. Fertilizer was applied and incorporated on 19 May as follows: control and standard $=26 \mathrm{~N}-11 \mathrm{P}-21 \mathrm{~K}$ $\left(\mathrm{kg} \cdot \mathrm{ha}^{-1}\right)$; intermediate $=71 \mathrm{~N}-31 \mathrm{P}-58 \mathrm{~K}$ $\left(\mathrm{kg} \cdot \mathrm{ha}^{-1}\right)$; highest $=116 \mathrm{~N}-51 \mathrm{P}-95 \mathrm{~K}\left(\mathrm{~kg} \cdot \mathrm{ha}^{-1}\right)$. Seeds were sown on 15 June (there was a delay in planting due to persistent rains). Plants in HD plots were destructively harvested by machine on 18 Aug. Plants were topdressed on 23 Aug. A total of 27 harvests were made in control plots starting on 4 Aug. and ending on 9 Oct. A sampling only for $\mathrm{N}$ concentration in stems was made on 13 Oct.

Stillwater, 1995. A preplant soil test indicated $25 \mathrm{~N}-131 \mathrm{P}-361 \mathrm{~K}\left(\mathrm{~kg} \cdot \mathrm{ha}^{-1}\right)$. Fertilizer was applied and incorporated on 14 June as follows: control and standard $=20 \mathrm{~kg} \cdot \mathrm{ha}^{-1}$ of $\mathrm{N}$; intermediate $=65 \mathrm{~kg} \cdot \mathrm{ha}^{-1}$ of $\mathrm{N}$; highest $=110$ $\mathrm{kg} \cdot \mathrm{ha}^{-1}$ of N. Seeds were sown on 16 June. Four plants per plot were sampled on 28 Aug., after which plants in HD plots were destructively harvested by machine. Plants were topdressed on 1 Sept. A total of 14 harvests were made in control plots starting on 13 Aug. and ending on 5 Oct.

Bixby, 1996. A preplant soil test indicated 10N-111P-272K $\left(\mathrm{kg} \cdot \mathrm{ha}^{-1}\right)$. Fertilizer was applied and incorporated on 9 May as follows: control and standard $=35 \mathrm{~kg} \cdot \mathrm{ha}^{-1}$ of $\mathrm{N}$; intermediate $=80 \mathrm{~kg} \cdot \mathrm{ha}^{-1}$ of $\mathrm{N}$; highest $=125$ $\mathrm{kg} \cdot \mathrm{ha}^{-1}$ of N. Seeds were sown on 20 May. Four plants per plot were sampled on 12 July. Plants in HD plots were destructively harvested by machine on 15 July. Plants were topdressed on 19 July. Regrowth was sufficient to justify a second destructive mechanical harvest of plants in HD plots on 26 Aug. Plants were topdressed on 6 Sept., but no further harvests were made in HD plots. A total of 32 harvests were made in control plots starting on 9 July and ending on 25 Sept.

Statistical analysis. Each experiment was analyzed separately. Data were evaluated by analysis of variance procedures. Trend analysis was used to test for linear and quadratic effects of $\mathrm{N}$ rate within the three $\mathrm{N}$ treatments applied to the densely planted okra. Least squares means were used to compare the control to the three HD treatments.

\section{Results and Discussion}

Increasing $\mathrm{N}$ rates from standard to highest had no significant effect on total marketable, overmature, cull, and overall total fruit yields of densely planted okra in all three experiments (Tables 1, 2, and 3). This occurred even when stem $\mathrm{N}$ concentrations of densely planted okra equaled (Stillwater, 1995) or exceeded (Bixby, 1996) those of control plants (Table 4). McFerran et al. (1963) found that different rates of sidedressed $\mathrm{N}$ had no effect on ' $\mathrm{Clem}$ son Spineless' okra grown at three different within-row spacings. Albregts and Howard (1974) grew okra at three plant populations with two rates of $\mathrm{N}-\mathrm{P}-\mathrm{K}$ and concluded that the fertility levels they tested did not affect the yield-plant density response. Several researchers have reported that the major yield response of okra to $\mathrm{N}$ comes with the first increment above a zero-N baseline, with limited yield benefits from higher $\mathrm{N}$ rates (Ahmad and Tulloch-Reid, 1968; Asif and Greig, 1972; Fatokun and Chheda, 1983).

The highest $\mathrm{N}$ rate tended to delay fruit production. This was most evident in the quadratic decrease in marketable fruit weight as $\mathrm{N}$ rate increased at first harvest in the 1996

Table 1. Fruit yield response of destructively harvested, densely planted $(25 \times 23 \mathrm{~cm})$ okra to fertilizer treatments, Bixby, Okla., 1995.

\begin{tabular}{|c|c|c|c|c|c|c|}
\hline \multirow[b]{2}{*}{ Treatment $^{2}$} & \multicolumn{5}{|c|}{ Fruit fresh wt $\left(\mathrm{kg} \cdot \mathrm{ha}^{-1}\right)$} & \multirow{2}{*}{$\begin{array}{l}\text { Marketable fresh } \\
\text { fruit wt as a percent } \\
\text { of the control }\end{array}$} \\
\hline & Immature & Marketable $^{y}$ & Overmature & Cull & $\overline{\text { Total }}$ & \\
\hline Standard & 46 & $184^{* *}$ & 4466 & 157 & 4853 & 2.1 \\
\hline Intermediate & 43 & $351^{* *}$ & 5429 & 145 & 5968 & 3.9 \\
\hline Highest & 45 & $313^{* *}$ & 5024 & 214 & 5596 & 3.9 \\
\hline \multicolumn{7}{|c|}{ Contrasts within treatments } \\
\hline $\mathrm{N}$ linear & NS & NS & NS & NS & NS & NS \\
\hline $\mathrm{N}$ quadratic & NS & NS & NS & NS & NS & NS \\
\hline
\end{tabular}

${ }^{\mathrm{z}} \mathrm{A}$ preplant soil test indicated $19 \mathrm{~N}-154 \mathrm{P}-271 \mathrm{~K}\left(\mathrm{~kg} \cdot \mathrm{ha}^{-1}\right)$. Preplant fertilizer treatments were: standard = $26 \mathrm{~N}-11 \mathrm{P}-21 \mathrm{~K}\left(\mathrm{~kg}^{2} \mathrm{ha}^{-1}\right)$; intermediate $=71 \mathrm{~N}-31 \mathrm{P}-58 \mathrm{~K}\left(\mathrm{~kg} \cdot \mathrm{ha}^{-1}\right)$; highest $=116 \mathrm{~N}-51 \mathrm{P}-95 \mathrm{~K}\left(\mathrm{~kg} \cdot \mathrm{ha}^{-1}\right)$. ${ }^{\mathrm{y}}$ Control plants were spaced at $90 \times 23 \mathrm{~cm}$, received $26 \mathrm{~N}-11 \mathrm{P}-21 \mathrm{~K}\left(\mathrm{~kg} \cdot \mathrm{ha}^{-1}\right)$ preplant and $22 \mathrm{~kg} \cdot \mathrm{ha}^{-1}$ of $\mathrm{N}$ topdressed, and were repeatedly harvested by hand. The mean marketable fruit yield from the control was $9554 \mathrm{~kg} \cdot \mathrm{ha}^{-1}$. Within this column, means followed by the ** symbol differed from the control at $P \leq$ 0.01 by least squares.

Ns Nonsignificant at $P \leq 0.05$.

Table 2. Fruit yield response of destructively harvested, densely planted $(25 \times 23 \mathrm{~cm})$ okra to $\mathrm{N}$ treatments, Stillwater, Okla., 1995.

\begin{tabular}{|c|c|c|c|c|c|c|}
\hline \multirow[b]{2}{*}{$\mathrm{N}$ treatment $^{2}$} & \multicolumn{5}{|c|}{ Fruit fresh wt $\left(\mathrm{kg} \cdot \mathrm{ha}^{-1}\right)$} & \multirow{2}{*}{$\begin{array}{l}\text { Marketable fresh } \\
\text { fruit wt as a percen } \\
\text { of the control }\end{array}$} \\
\hline & Immature & Marketable $^{y}$ & Overmature & Cull & Total & \\
\hline Standard & 260 & $1496^{* *}$ & 1644 & 26 & 3426 & 17.9 \\
\hline Intermediate & 224 & $1102^{* *}$ & 1748 & 20 & 3094 & 13.2 \\
\hline Highest & 204 & $1032^{* *}$ & 1349 & 22 & 2606 & 12.3 \\
\hline \multicolumn{7}{|c|}{ Contrasts within $N$ treatments } \\
\hline $\mathrm{N}$ linear & $*$ & NS & NS & NS & NS & NS \\
\hline $\mathrm{N}$ quadratic & NS & NS & NS & NS & NS & NS \\
\hline
\end{tabular}

${ }^{7}$ A preplant soil test indicated $25 \mathrm{~N}-131 \mathrm{P}-361 \mathrm{~K}\left(\mathrm{~kg}^{-h^{-1}}\right)$. Preplant $\mathrm{N}$ fertilizer treatments were: standard $=20 \mathrm{~kg} \cdot \mathrm{ha}^{-1}$; intermediate $=65 \mathrm{~kg} \cdot \mathrm{ha}^{-1} ;$, highest $=110 \mathrm{~kg} \cdot \mathrm{ha}^{-1}$.

${ }^{y}$ Control plants were spaced at $90 \times 23 \mathrm{~cm}$, received $20 \mathrm{~kg} \cdot \mathrm{ha}^{-1}$ of $\mathrm{N}$ preplant and $22 \mathrm{~kg} \cdot \mathrm{ha}^{-1}$ of $\mathrm{N}$ topdressed, and were repeatedly harvested by hand. The mean marketable fruit yield from the control was $8437 \mathrm{~kg} \cdot \mathrm{ha}^{-1}$. Within this column, means followed by the $* *$ symbol differed from the control at $P \leq 0.01$ by least squares.

Ns, ${ }^{*}$ Nonsignificant or significant at $P \leq 0.05$, respectively. 
Table 3. Fruit yield response of densely planted $(25 \times 23 \mathrm{~cm})$ okra to $\mathrm{N}$ treatments at each of two destructive harvests, Bixby, Okla., 1996. ${ }^{2}$

\begin{tabular}{|c|c|c|c|c|c|c|c|c|c|c|c|c|}
\hline \multirow[b]{3}{*}{$\mathrm{N}$ treatment $\mathrm{t}^{\mathrm{y}}$} & \multicolumn{11}{|c|}{ Fruit fresh wt $\left(\mathrm{kg} \cdot \mathrm{ha}^{-1}\right)$} & \multirow{3}{*}{$\begin{array}{l}\text { Total marketable } \\
\text { fresh fruit wt as a } \\
\text { percent of the control }\end{array}$} \\
\hline & \multicolumn{2}{|c|}{ Immature } & \multicolumn{3}{|c|}{ Marketable $^{y}$} & \multicolumn{2}{|c|}{ Overmature } & \multicolumn{2}{|c|}{ Cull } & \multicolumn{2}{|c|}{ Total } & \\
\hline & $\mathrm{H} 1$ & $\mathrm{H} 2$ & $\mathrm{H} 1$ & $\mathrm{H} 2$ & $\operatorname{Total}^{\mathrm{x}}$ & $\mathrm{H} 1$ & $\mathrm{H} 2$ & $\overline{\mathrm{H} 1}$ & $\mathrm{H} 2$ & $\mathrm{H} 1$ & $\overline{\mathrm{H} 2}$ & \\
\hline Standard & 58 & 276 & 418 & 789 & $1206^{* *}$ & 603 & 4860 & 38 & 248 & 1116 & 6174 & 9.1 \\
\hline Intermediate & 58 & 260 & 436 & 740 & $1176^{* *}$ & 614 & 4349 & 41 & 282 & 1149 & 5631 & 8.9 \\
\hline Highest & 58 & 277 & 301 & 735 & $1036^{* *}$ & 427 & 4598 & 47 & 300 & 833 & 5910 & 7.9 \\
\hline \multicolumn{13}{|c|}{ Contrasts within $N$ treatments } \\
\hline $\mathrm{N}$ linear & NS & NS & $* *$ & NS & NS & NS & NS & NS & NS & $*$ & NS & NS \\
\hline $\mathrm{N}$ quadratic & NS & NS & $*$ & NS & NS & NS & NS & NS & NS & NS & NS & NS \\
\hline
\end{tabular}

${ }^{\mathrm{z}} \mathrm{H} 1$ = first machine harvest, 15 July. H2 = second machine harvest, 26 Aug.

${ }^{y}$ A preplant soil test indicated $10 \mathrm{~N}-111 \mathrm{P}-272 \mathrm{~K}\left(\mathrm{~kg} \cdot \mathrm{ha}{ }^{-1}\right)$. Preplant $\mathrm{N}$ fertilizer treatments were: standard $=35 \mathrm{~kg} \cdot \mathrm{ha}^{-1}$; intermediate $=80 \mathrm{~kg} \cdot \mathrm{ha}^{-1}$; highest $=125 \mathrm{~kg} \cdot \mathrm{ha}^{-1}$. Topdress $\mathrm{N}$ fertilizer treatments on $19 \mathrm{July}$ were: standard $=22 \mathrm{~kg} \cdot \mathrm{ha} \mathrm{a}^{-1}$; intermediate $=$ $44 \mathrm{~kg} \cdot \mathrm{ha}^{-1}$; highest $=66 \mathrm{~kg} \cdot \mathrm{ha}^{-1}$.

${ }^{\mathrm{x}}$ Control plants were spaced at $90 \times 23 \mathrm{~cm}$, received $35 \mathrm{~kg} \cdot \mathrm{ha}^{-1}$ of $\mathrm{N}$ preplant, $22 \mathrm{~kg} \cdot \mathrm{ha}^{-1}$ of N topdressed on $19 \mathrm{July}$ and $22 \mathrm{~kg} \cdot \mathrm{ha}{ }^{-1}$ of $\mathrm{N}$ topdressed on $26 \mathrm{Aug}$., and were repeatedly harvested by hand. The mean marketable fruit yield from the control was 13,217 $\mathrm{kg} \cdot \mathrm{ha}^{-1}$. Within this column, means followed by the ** symbol differed from the control at $P \leq 0.01$ by least squares.

Ns, *, ${ }^{* *}$ Nonsignificant or significant at $P \leq 0.05$ or 0.01 , respectively.

Table 4. Further comparisons of densely planted $(25 \times 23 \mathrm{~cm})$ okra to a conventionally spaced $(90 \times 23 \mathrm{~cm}) \mathrm{control} .^{2}$

\begin{tabular}{|c|c|c|c|c|c|c|c|c|c|c|}
\hline \multirow[b]{2}{*}{ Treatment $^{\mathrm{y}}$} & \multicolumn{3}{|c|}{ Plants per ha $\times 10^{3}$} & \multicolumn{3}{|c|}{ Stem N concn $(\%)$} & \multicolumn{2}{|c|}{$\begin{array}{c}\mathrm{Ht}(\mathrm{cm}) \\
\text { from soil to } \\
\text { highest plant part }\end{array}$} & \multicolumn{2}{|c|}{$\begin{array}{c}\text { Defruited dry } \\
\text { wt (g/plant) }\end{array}$} \\
\hline & ${\operatorname{Bix} 95^{x}}$ & Stw95 & $\overline{\operatorname{Bix} 96^{x}}$ & Bix95 & Stw95 & Bix96 & Stw95 & Bix96 & Stw95 & Bix96 \\
\hline Control & 41.5 & 43.3 & 41.1 & 2.7 & 2.5 & 3.1 & 106 & 31 & 126 & 39 \\
\hline Standard & $109.0^{* *}$ & $109.4^{* *}$ & $76.7^{* *}$ & $1.2^{* *}$ & $1.9^{*}$ & 3.4 & $138^{* *}$ & 36 & $54^{* *}$ & $21^{* *}$ \\
\hline Intermediate & $109.8^{* * *}$ & $105.2^{* *}$ & $77.0^{* *}$ & $1.8^{* *}$ & $2.0^{*}$ & $3.9^{* *}$ & $137^{* *}$ & 36 & $56^{* *}$ & $25^{* *}$ \\
\hline Highest & $108.6^{* *}$ & $105.1^{* *}$ & $75.6^{* *}$ & $2.2^{* *}$ & 2.2 & $4.4^{* *}$ & $137^{* *}$ & 35 & $55^{* *}$ & $26^{* *}$ \\
\hline \multicolumn{11}{|c|}{ Contrasts within standard, intermediate, and highest fertilizer treatments } \\
\hline $\mathrm{N}$ linear & NS & NS & NS & $* *$ & NS & $* *$ & NS & NS & NS & NS \\
\hline $\mathrm{N}$ quadratic & NS & NS & NS & NS & NS & NS & NS & NS & NS & NS \\
\hline
\end{tabular}

${ }^{\mathrm{z}}$ Within columns, means followed by the $*$ or $* *$ symbols differed from the control at $P \leq 0.05$ or 0.01 , respectively, by least squares.

${ }^{y}$ See text and preceding tables for details of control fertilization rates and fertilizer treatments.

xLocation/year abbreviations: Bix95 = Bixby, 1995; Stw95 = Stillwater, 1995; Bix96 = Bixby, 1996.

ns, *,**Nonsignificant or significant at $P \leq 0.05$ or 0.01 , respectively.

but increased shoot dry weight from $\mathrm{N}$ applications on conventionally spaced okra. The high plant populations in our studies inconsistently affected plant height, as others have noted (Gupta et al., 1981; Hermann et al., 1990). Control plants also were heavier than densely spaced plants (Table 4), as we had found in other studies (Wu et al., 2003b).

A key finding was that increasing $\mathrm{N}$ rates did not increase the marketable fruit yield obtained by mechanical harvest of the densely spaced plants, expressed as a percentage of the total cumulative marketable yield from control plants (Tables 1, 2, and 3). This is evidence that $\mathrm{N}$ nutrition does not limit the potential for densely planted okra in a destructive mechanical harvest system. Unfortunately, percentages of marketable yield obtained by destructive harvests of high-population plots were low relative to the cumulative marketable yield from control plots in the present studies (Tables 1,2, and 3) and in other studies (Wu et al., 2003a). Physiological factors, primarily the lack of a concentrated marketable fruit set (Düzyaman, 1997), appear to be limiting the potential for densely planted okra in a destructive mechanical harvest system rather than horticultural factors such as $\mathrm{N}$ nutrition.

\section{Literature Cited}

Ahmad, N. and L.I. Tulloch-Reid. 1968. Effect of fertilizer nitrogen, phosphorus, potassium and magnesium on yield and nutrient content of okra (Hibiscus esculentus L.). Agron. J. 60: 353-356.

Albregts, E.E. and C.M. Howard. 1974. Response of okra to plant density and fertilization. HortScience 9:400.

Asif, M.I. and J.K. Greig. 1972. Effects of N, P, and $\mathrm{K}$ fertilization on fruit yield, macro- and micronutrient levels, and nitrate accumulation in okra [Abelmoschus esculentus (L.) Moench]. J. Amer. Soc. Hort. Sci. 97:440-442.

Düzyaman,E. 1997. Okra: Botany and horticulture, p. 41-72. In: J. Janick (ed.). Horticultural reviews, vol. 21. Wiley, New York.

Fatokun, C.A. and H.R. Chheda. 1983. The effects of nitrogen and phosphorus on yield and chemical composition of okra [Abelmoschus esculentus (L.) Moench]. Acta Hort. 123:283-290.

Gupta, A., K. Srinivas, and V. Shukla. 1981. Response of okra (Abelmoschus esculentus L.) to plant spacing and nitrogen, phosphorus fertilization. Indian J. Hort. 38:218-222.

Hermann, M., M. Makadji, and H.J. Daunicht. 1990. Effect on intra-row spacing on time course of growth and fruit yield of okra. Scientia Hort. 45:37-48.

Majanbu, I.S., V.B. Ogunlela, M.K. Ahmed, and J.D. Olarewaju. 1985. Response of two okra
(Abelmoschus esculentus L. Moench) varieties to fertilizers: Yield and yield components as influenced by nitrogen and phosphorus application. Fert. Res. 6:257-267.

Majanbu, I.S., V.B. Ogunlela, and M.K. Ahmed. 1986. Response of two okra (Abelmoschus esculentus L. Moench) varieties to fertilizers: Growth and nutrient concentration as influenced by nitrogen and phosphorus application. Fert. Res. 8:297-306.

McFerran, J., G.A. Bradley, and H.L. Bowden. 1963. Production of Clemson Spineless okra. Ark. Farm Res. 12(2):10.

Motes, J.E., D. Benson, J.T. Criswell, and G.L. Barnes. 1982. Okra production. OSU Ag Facts No. 6025. Coop. Ext. Serv., Okla. State Univ., Stillwater.

Shrestha, G.K. 1983. Effects of spacing and nitrogen fertilizer on 'Pusa Sawani' okra (Abelmoschus esculentus) in Nepal. Expt. Agr. 19:239-242.

Windham, S.L. 1966. Fertilizer study shows rates for okra production. Miss. Farm Res. 29(3):5-6.

Wu, Y., B.A. Kahn, N.O. Maness, J.B. Solie, R.W. Whitney, and K.E. Conway. 2003a. Densely planted okra for destructive harvest: I. Effects on yield. HortScience 38:1360-364.

Wu, Y., B.A. Kahn, N.O. Maness, J.B. Solie, R.W. Whitney, and K.E. Conway. 2003b. Densely planted okra for destructive harvest: II. Effects on plant architecture. HortScience 38: 1365-1369. 